\title{
Aqueous Two-Phase Systems Applied to Partition Proteins from Goat Milk Whey In-Nature
}

\author{
Luziany A. C. Freire, Camila G. Pereira* \\ Department of Chemical Engineering, Federal University of Rio Grande do Norte, Natal, Brazil \\ Email: *camila@eq.ufrn.br
}

How to cite this paper: Freire, L.A.C. and Pereira, C.G. (2016) Aqueous Two-Phase Systems Applied to Partition Proteins from Goat Milk Whey In-Nature. Advances in Bioscience and Biotechnology, 7, 350-359. http://dx.doi.org/10.4236/abb.2016.79034

Received: June 12, 2016

Accepted: September 10, 2016

Published: September 13, 2016

Copyright (c) 2016 by authors and Scientific Research Publishing Inc. This work is licensed under the Creative Commons Attribution International License (CC BY 4.0).

http://creativecommons.org/licenses/by/4.0/

\begin{abstract}
The proteins coming from the milk whey have numerous functional properties. Among the proteins with high bioactivity, $\alpha$-lactoalbumin ( $\alpha$-La) and $\beta$-lactoglobulin $(\beta-\mathrm{Lg})$ are present in large quantities in the milk whey. In the separation process of proteins, it is important to choose techniques which besides ensuring purity and high yield will not affect the molecule biological activity. The aqueous two-phase systems (ATS) have been utilized with success in the partition of these proteins, however, the studies were performed using protein in its pure form. Studies using milk whey in-nature and goat milk whey have not been found yet. In this context, the objective of this study was to evaluate the liquid liquid equilibrium of aqueous two-phase systems (ATS) in the partition of $\alpha-\mathrm{La}$ and $\beta$-Lg from goat milk whey in-nature. Equilibrium data were performed considering ATS comprised of polyethylene glycol, potassium phosphate and water at $25^{\circ} \mathrm{C}$ and $\mathrm{pH}$ 7.0. The influence of the polymer molecular weight and amount of goat milk whey in-nature on the partition coefficient of these proteins were assessed. The partition coefficient, selectivity, process yield and purity of $\alpha$-lactoalbumin and $\beta$-lactoglobulin proteins were determined. The results showed that the separation technique by aqueous biphasic systems is applicable indicating high efficiency in the whey proteins separation process.
\end{abstract}

\section{Keywords}

Goat Milk Whey, $\alpha$-Lactoalbumin, $\beta$-Lactoglobulin, Aqueous Biphasic Systems

\section{Introduction}

The whey consists of the aqueous fraction obtained as result of the milk coagulation during cheese production or in casein production; it retains about $55 \%$ of milk nutrient [1]. Studies show that the amount of protein presents in the goat milk whey is higher 
(1.3\%) than that presented in the bovine milk whey (0.85\%) [2]. Among whey proteins the $\alpha$-lactoalbumin $(\alpha-\mathrm{La})$ and $\beta$-lactoglobulin $(\beta$-Lg) are those which are present in large quantities (more than 50\%) [3]. Due to the bioactive activity of these molecules, the separation process choice is a critical step, since it is desired obtaining functional compounds of quality.

Most protein purification processes involves several steps and solvent consumption. Aqueous two-phase systems (ATS) have been applied with success in the recovery of biomolecules from natural products [4]. The simplicity, the low cost and efficiency of phase forming allow this method for large-scale purification. Two aqueous phases consist of a system containing two hydrophilic polymers or a polymer and an inorganic salt.

An aqueous biphasic system can be formed by different ways, mixing two hydrophilic polymers or a polymer and salt organic or inorganic [5]-[8]. ATSs have demonstrated higher potential in the recovery of biomolecules, allowing to isolate and to concentrate compounds with bioactivity from complex mixtures, as proteins.

Due to the high water content presented in the aqueous biphasic systems, around $80 \%$ to $90 \%$, and the low interfacial tension, it is possible to separate bio-molecules under mild conditions in a suitable environment, without affecting its biological activity [9] [10]. The simplicity, the low cost and efficiency of phase forming allow this method for large-scale purification.

The partition of $\alpha$-La e $\beta$-Lg using ATSs has been presented in literature by applying of different systems, such as Polyethylene glycol (PEG) + sodium citrate + water and PEG + potassium phosphate + water [11], PEG + maltodextrin + water [12], polyvinylpyrrolidone (PVP) + potassium phosphate + water [13]. However, all these studies were performed using protein in its pure form. Studies using milk whey in-nature and goat milk whey have not been found yet.

In this sense, the aim of this study was to evaluate the liquid liquid equilibrium of aqueous two-phase systems applied to the partition of $\alpha$-La and $\beta$ - $L$ g from goat milk whey in-nature. The aqueous two-phase systems were formed by polyethylene glycol (PEG), potassium phosphate (KPi) and water. All systems were maintained at $298 \mathrm{~K}$ and $\mathrm{pH}$ 7.0. The partition coefficient, selectivity, process yield and purity of $\alpha$-La e $\beta$-Lg proteins were determined. The amount of the goat milk whey in-nature necessary for the separation and the influence of the polymer molecular weight on the partition of these proteins were also evaluated.

\section{Materials and Methods}

\subsection{Materials and Reagents}

The goat milk whey was provided by Association of Small Ranchers of the Angicos wilderness (Associação dos Pequenos Agropecuaristas do Sertão de Angicos-APASA). The polymers utilized were PEG of molecular weight 1500 Daltons (Impex-Lot 35263-D), 4000 (Synth-Lot 152264), 8000 (Sigma-Lot 120M0004V). The salt utilized was potassium phosphate (KPi), monobasic (Vetec-Lot 1200572, Purity 99\%) and dibasic 
(Isofar-Lot 111027, Purity 98\%). In all systems, deionized water was used. The samples were filtered, filtered through cellulose acetate membrane with a porosity of $0.45 \mu \mathrm{m}$ using acetonitrile (Sigma, Lot SHBD1824V, Purity 99.9\%) and trifluoroacetic acid (Sigma-Lot BCBM0756V, Purity 99\%).

\subsection{Liquid Liquid Equilibrium Data}

The aqueous biphasic systems were formed according to the methodology described by Coimbra et al. [11] and Alves [14]. Three molecular weight of PEG (1500, 4000, and 8000 ) were tested. The binodal curve was determined by the cloud point method using titration procedure. The tie-lines were determined using the methodology described by Jorge [15]. Both analyzes were performed in an equilibrium cell connected to a thermostatic bath at $298 \mathrm{~K}$. Calibration curves were constructed considering the mass fraction of each component versus density in order to quantify the compositions of equilibrium phases. The curves were compiled with the points of the binodal curve, where the density of the mixture was measured at the cloud point, and the liquid-liquid equilibrium data of the ternary system were plotted using the Oringin 7.0.

\subsection{Quantification of $\alpha$-La and $\beta$-Lg Proteins in Goat Milk Whey}

The quantification of $\alpha$-La and $\beta$-Lg protein was performed by high performance liquid chromatography (Shimadzu, Prominence, Kyoto, Japan series) containing a ternary pumping system (LC-20AT), autosampler (SIL-20AHT), column oven (CTO-20A), detector per diode array (SPD-M20A) and interface (CBM-20A). LC solution data were evaluated using an acquisition software, version 1.25 and Rigaku data treatment. The chromatographic separation occurred in reversed phase, the column and parameters utilized were the same as presented in Buffoni [16], a Jupiter C4 column (2504.6 mm, $300 \AA$ pore size, $5 \mu \mathrm{m}$ particle size, Phenomenex) was used, the oven temperature was $30^{\circ} \mathrm{C}$, mobile phase flow equal to $1 \mathrm{~mL} / \mathrm{min}$, injection volume equal to $20 \mu \mathrm{L}$, the eluent was monitored using a detector per diode array at $205 \mathrm{~nm}$. The eluents solutions and elution gradient utilized were the same described by Enne [17], where the mobile phase (A) was composed of water of HPLC grade containing $0.1 \%$ of trifluoroacetic acid, and mobile phase (B) was composed of Acetonitrile containing $0.1 \%$ of trifluoroacetic acid. The elution gradient was 35\% B from 0 to $1 \mathrm{~min}, 35 \%$ - 38\% B from 1 to $8 \mathrm{~min}, 38 \%$ $42 \%$ B from 8 to $16 \mathrm{~min}, 42 \%-46 \%$ B from 16 to $22 \mathrm{~min}, 46 \%-90 \%$ B from 22 to 24 minutes, $90 \%$ B from 24 to $25 \mathrm{~min}, 90 \%$ - 35\% B from 25 to $30 \mathrm{~min}, 35 \%$ from 30 to 35 $\min$.

\subsection{Partition Process Analysis}

The separation process was evaluated in terms of partition coefficient, selectivity, yield and purity, which were determined through as described below.

a) Partition Coefficient $(K)$ : it was determined considering the ratio between the protein concentration in the upper phase and the concentration of the same protein in the lower phase: 


$$
K=\frac{C_{U P}}{C_{L P}}
$$

where $K$ is the partition coefficient, $C_{U P}$ and $C_{L P}$ are the protein concentrations in the upper and lower phase, respectively.

b) Selectivity: it is defined by the ratio between the partition coefficients of $\alpha$-La and $\beta$-Lg in the two balance phases:

$$
S=\frac{K_{\alpha L a}}{K_{\beta L g}}
$$

where $S$ represents selectivity of $\alpha$-La compared to $\beta-\mathrm{Lg}, K_{\alpha L a}$ and $K_{\beta L g}$ are the partition coefficients of $\alpha$-La and $\beta$-Lg, respectively.

c) Yield and Purity: These two values were calculated according to equations defined by Chen [18]. For the $\alpha$-La and $\beta$-Lg proteins yield:

$$
Y_{\alpha L a, U P}=\frac{100}{\left(1+\left(\frac{1}{V_{r}} \times \frac{1}{K_{\alpha L a}}\right)\right)}
$$

where $Y_{\alpha L a, U P}$ and $K_{\beta L g, L P}$ correspond to $\alpha$-La yield in the upper phase and $\beta$-Lg yield in the lower phase, respectively; $K_{\alpha L a}$ and $K_{\beta L g}$ are the partition coefficients of $\alpha$-La and $\beta$ - $\mathrm{Lg}$, respectively; $V_{r}$ correspond to the volume ratio between the phases.

And for the $\alpha-\operatorname{La}$ and $\beta-\operatorname{Lg}$ proteins purity:

$$
\begin{aligned}
& P_{\alpha L a, U P}=100 \times Y_{\alpha L a, U P} \times \frac{0.7}{\left(Y_{\alpha L a, U P} \times 0.7\right)+\left(100-Y_{\alpha L a, U P}\right) \times 3} \\
& P_{\beta L g, L P}=100 \times Y_{\beta L g, L P} \times \frac{3}{\left(100-Y_{\beta L g, L P}\right) \times 0.7+\left(Y_{\beta L g, L P} \times 3\right)}
\end{aligned}
$$

where $P_{\alpha L a, U P}$ and $P_{\beta L g, L P}$ correspond to the purity percentage of $\alpha$-La proteins in the upper phase and $\beta$-Lg in the lower phase, respectively.

\section{Results and Discussions}

\subsection{Effect of the Molecular Mass of the Polymer}

Figure 1 presents the phase diagram for the system polyethylene glycol, potassium phosphate and water considering different molecular mass of PEG. The deviation in the experimental data of the bimodal curves was $4.01 \%$.

According to Figure 1, it's possible to observe that the molecular mass of the polymer affects the equilibrium. The system formed by PEG 8000 presents higher biphasic region, decreasing the region when PEG 4000 is used and even more when PEG 1500 is applied. This result is coherent with literature [19] [20].

To determine tie-line, different methodologies can be used. Chumpitaz [21] also evaluated the system consisted by PEG $1500+\mathrm{KPi}+$ water in several conditions. Figure 2 presents the lie-lines determined by Chimpitaz [21] and in this work using the methodology described by Jorge [15], both in the same conditions of temperature, pressure, $\mathrm{pH}$, and global composition of ATS. 


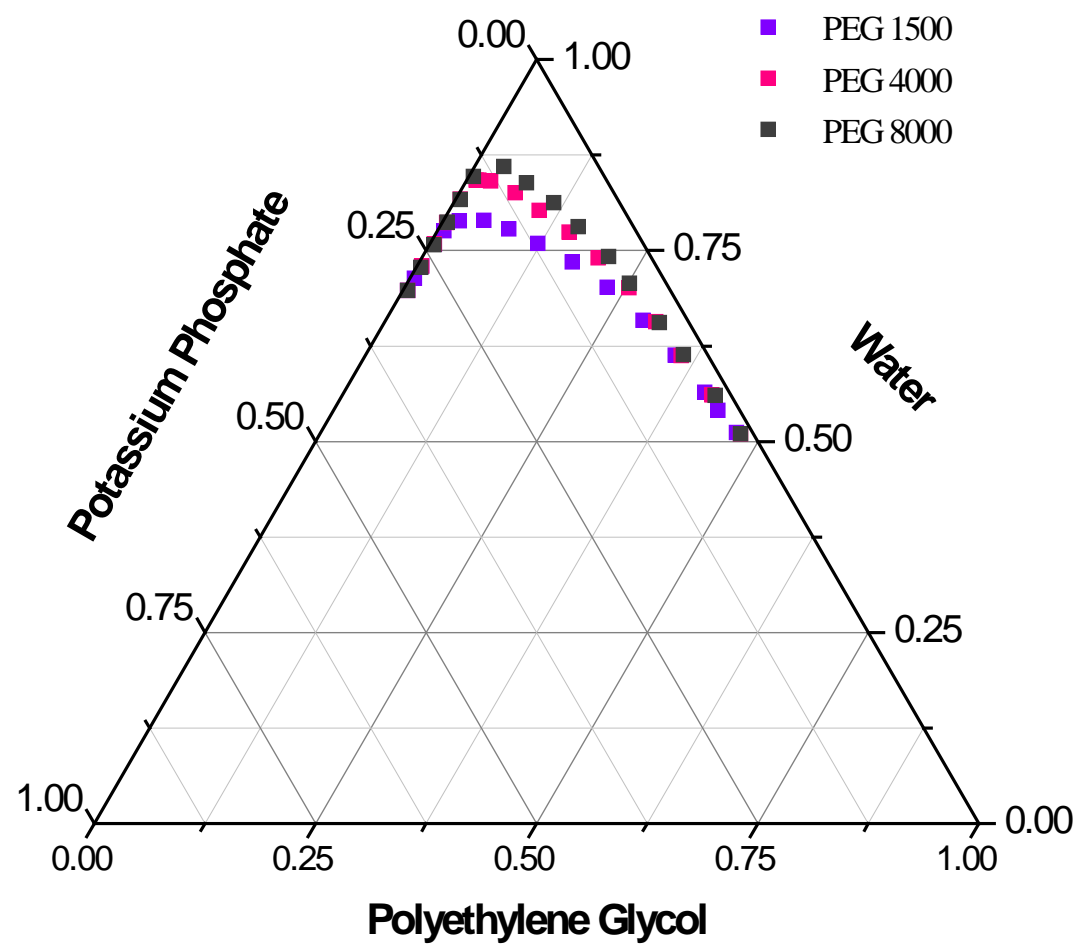

Figure 1. Ternary diagram for the system PEG $(1500,4000,8000)+\mathrm{KPi}+$ water at $298 \mathrm{~K}$, and $101.3 \mathrm{kPa}$.

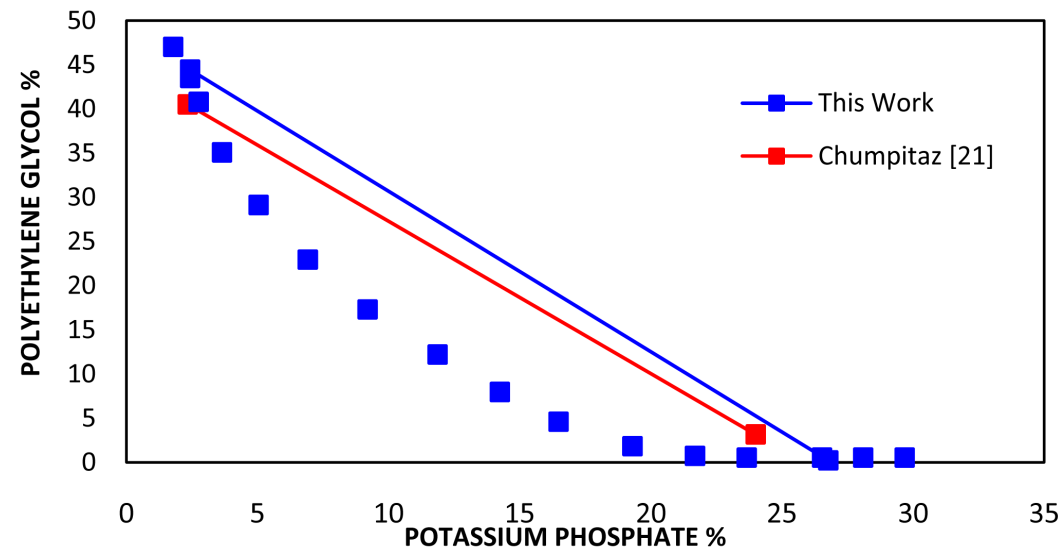

Figure 2. Binodal curve and tie-lines obtained for the system diagram for the system PEG (1500) $+\mathrm{KPi}+$ water at $298 \mathrm{~K}$, and $101.3 \mathrm{kPa}$, from this work and literature [21].

Good adjust of the tie-line can be observed for the tie-line obtained in this work (s.d $=0.01$ ). However, the tie-line obtained by Cumpitaz [21] presented a higher deviation mainly in the lower phase. To determine tie-lines, the author defined previously the global composition, and the composition of the phases was obtained by the quantification of the compounds by mass difference. Due to the better adjust of the methodology of Jorge [15], this methodology was kept for the other systems in this study. Figure 3 presents the binodal curves and tie-lines obtained for the system PEG (1500, 4000, $8000)+\mathrm{KPi}+$ water. 


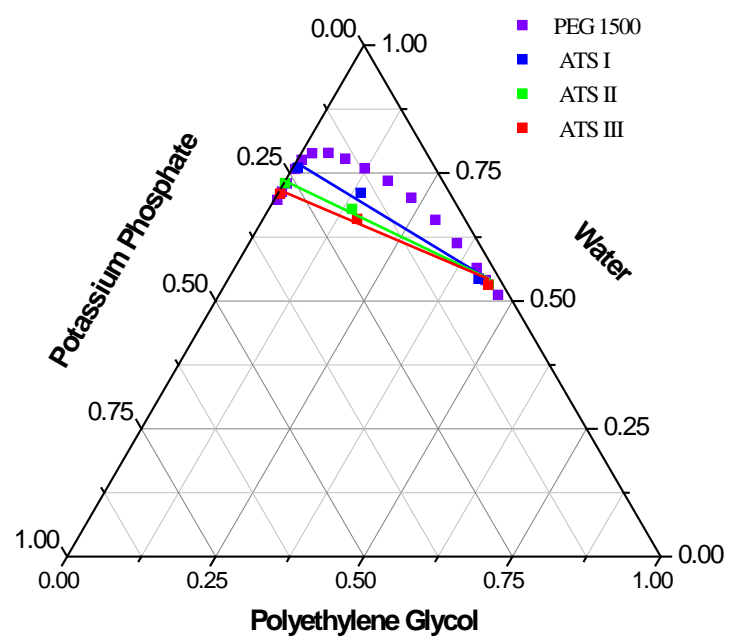

(a)

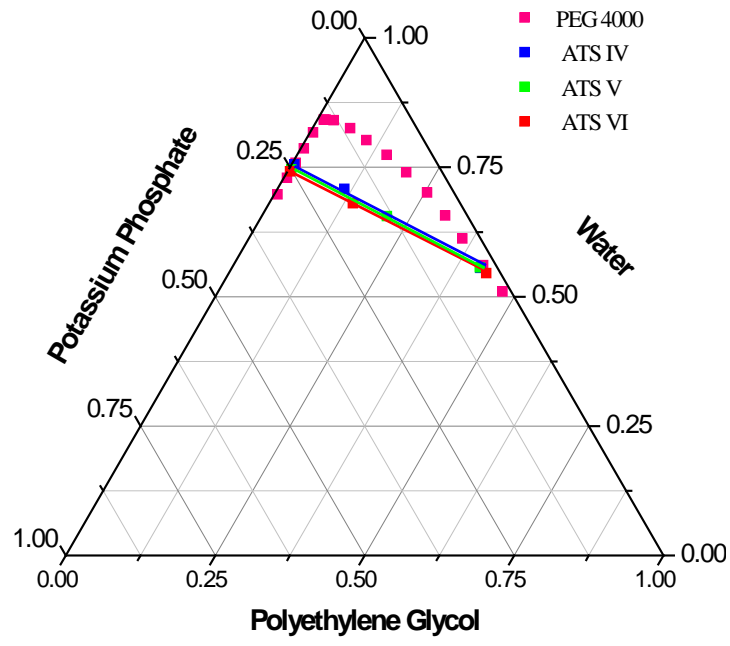

(b)

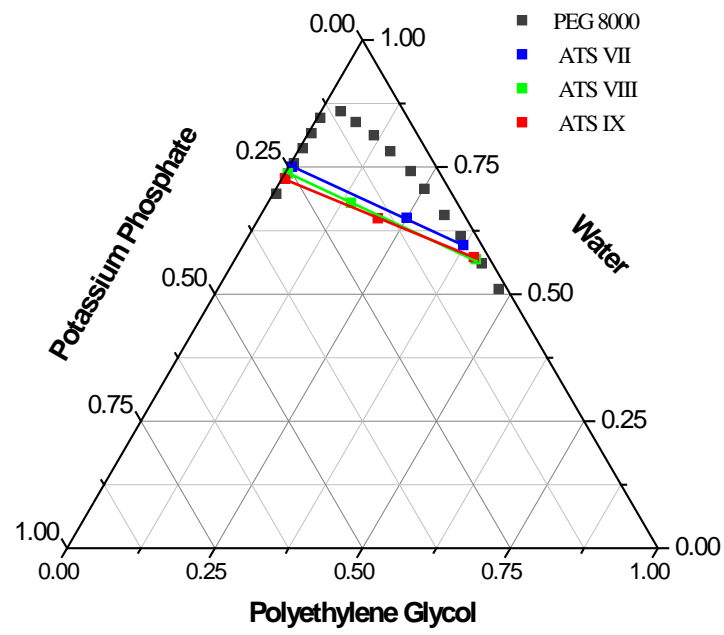

(c)

Figure 3. Ternary diagram for the system PEG-KPi-water at $298 \mathrm{~K}$, and $101.3 \mathrm{kPa}$, where (a) PEG-1500; (b) PEG-4000; (c) PEG-8000. 
From Figure 3, it's possible to observe the good adjust of all tie-lines. In all systems, the polymer was concentrated in the upper phase, and KPi in the lower phase.

\subsection{Partition of $\alpha$-La and $\beta$-Lg Proteins}

Table 1 shows the partition coefficient, selectivity and process yield and purity of $\alpha$-La and $\beta$-Lg proteins, when different amount of goat milk whey was employed. For this experiment, the aqueous two-phase systems were formed by $14 \%$ of PEG $1500,18 \%$ of KPi and $68 \%$ of water.

According to Table 1, the experiment using $1 \mathrm{~mL}$ of goat milk whey in-nature presented better partition coefficient $\left(K_{\alpha-L a}=5.78 ; K_{\beta-L g}=0.09\right)$, selectivity $(63.71)$, yield $\left(\alpha-L a_{F . u p}=78.61 ; \beta-L g_{F . l p}=94.54\right)$ and high purity $\left(\alpha-L a_{F . u p}=77.08 ; \beta-L g_{F \cdot l p}=94.99\right)$. This occurred due to it low amount of water. The increase of goat milk whey quantity in the aqueous two-phase systems promoted the increased of water in the global system, changing the equilibrium. This occurrence prevented the separation of proteins in the systems using higher amount of goat milk whey.

The results also demonstrated the efficiency of aqueous two-phase systems in the separation of these proteins, since $85 \%$ of $\beta$ - $\mathrm{Lg}$ was recovery in the lower phase, and $92 \%$ of $\alpha$-La in the upper phase.

It is important to emphasize that the partition coefficient of these proteins were coherent with studies of literature that also applied polyethylene glycol, potassium phosphate and water at the same operational conditions, however using pure $\alpha$ - $\mathrm{La} \mathrm{e} \beta$ - $\mathrm{Lg}$ proteins [22] [23]. This indicates the success of application of the aqueous two-phase in the real systems.

After the determination of the best amount of goat milk whey to be used, it was evaluated the partition of the proteins in the ATSs formed by PEG $(150,4000,8000)+\mathrm{KPi}$ + water. Table 2 presents the partition coefficient, selectivity and process yield and purity of $\alpha$-La and $\beta$-Lg proteins.

According to Table 2, the system formed by PEG 1500 presented higher partition coefficient for $\alpha$-La $\left(K_{\alpha-L a}=5.78\right)$, and lower partition coefficient for $\beta$-Lg. This system also presented a result of selectivity considered satisfactory, since the sample is a real sample, i.e., goat milk whey in nature with other compounds presents. The system containing PEG 8000 did not partitioned the proteins. Table 2 also shows that the results were coherent with literature, in which, increasing of molecular mass of poly-

Table 1. Partition coefficients, selectivity, yield and purity for of the $\alpha$-La e $\beta$-Lg proteins partitioned in aqueous two-phase systems, using different amounts of goat milk whey.

\begin{tabular}{|c|c|c|c|c|c|c|c|}
\hline \multirow{2}{*}{$\begin{array}{l}\text { Goat milk whey } \\
\text { amount (mL) }\end{array}$} & \multirow{2}{*}{$K_{\alpha-L a}$} & \multirow{2}{*}{$K_{\beta-L g}$} & \multirow{2}{*}{ Selectivity } & \multicolumn{2}{|c|}{ Yield (\%) } & \multicolumn{2}{|c|}{ Purity (\%) } \\
\hline & & & & $\alpha-L a_{\text {up }}$ & $\beta-\operatorname{Lg}_{1 p}$ & $\alpha-L a_{\text {up }}$ & $\beta-\operatorname{Lg}_{1 p}$ \\
\hline 1 & 5.78 & 0.09 & 63.71 & 78.61 & 94.54 & 77.08 & 94.99 \\
\hline 5 & 2.25 & 0.05 & 45.57 & 58.91 & 96.95 & 81.84 & 91.00 \\
\hline 10 & - & - & - & - & - & - & - \\
\hline
\end{tabular}

${ }^{*}$ up = upper phase, $\mathrm{lp}=$ lower phase. 
Table 2. Partition coefficients, selectivity, yield, purity and separation time of the $\alpha$ - $\mathrm{La}$ e $\beta$ - $\mathrm{Lg}$ proteins partitioned in aqueous two-phase systems formed by $14 \% \mathrm{PEG}+18 \% \mathrm{KPi}+68 \%$ water, using $1 \mathrm{~mL}$ of goat milk whey.

\begin{tabular}{|c|c|c|c|c|c|c|c|c|}
\hline \multirow{2}{*}{ PEG } & \multirow{2}{*}{$K_{\alpha-L a}$} & \multirow{2}{*}{$K_{\beta-L g}$} & \multirow{2}{*}{ Selectivity } & \multicolumn{2}{|c|}{ Yield (\%) } & \multicolumn{2}{|c|}{ Purity (\%) } & \multirow{2}{*}{$\begin{array}{c}\text { Separation } \\
\text { Time (s) }\end{array}$} \\
\hline & & & & $\alpha-\mathrm{La}_{u p}$ & $\beta-\mathrm{Lg}_{\mathrm{lp}}$ & $\alpha-L a_{u p}$ & $\beta-\operatorname{Lg}_{l p}$ & \\
\hline 1500 & 5.78 & 0.091 & 63.71 & 78.61 & 94.54 & 77.1 & 94.99 & 144 \\
\hline 4000 & 0.35 & - & - & 41.02 & 100 & 100 & 87.90 & 117 \\
\hline 8000 & - & - & - & - & - & - & - & 74 \\
\hline
\end{tabular}

${ }^{*}$ up $=$ upper phase, $\mathrm{lp}=$ lower phase.

mer promotes decreasing of the partition coefficient [9] [23]. This behavior is attributed to the increased of proportions of hydrophilic terminations groups in the polymer molecules with a lower molecular weight (or shorter chain length), this fact reduces the overall hydrophobicity of the polymer rich phase [9]. Besides, due to the lower viscosities, the polymers with lower molecular mass promoted fast time to get the equilibrium.

The results demonstrated good efficiency in the separation of proteins for the system consisted by PEG $1500+\mathrm{KPi}+$ water, where: $78.61 \%$ of $\alpha$-La was concentrated in the upper phase, and $95 \%$ of $\beta$-Lg was concentrated in the lower phase.

\section{Conclusion}

The results demonstrate that the phase diagram provided information about the condition to be applied in the recovery of whey protein in the two-phases. The amount of goat milk whey in-nature needs to be considered in order to promote the best separation of the proteins. The increase of the molecular weight of the polymer caused an increase in the biphasic region. On the other hand, increasing the polymer molecular weight caused a decrease in partition coefficient of the protein as well as a decrease in time separation of the phases the aqueous systems. The system consists of PEG $1500+$ $\mathrm{KPi}+$ water showed the best results in terms of partition coefficient, yield and purity of the $\alpha$-La e $\beta$-Lg proteins from goat milk whey in-nature. The results showed that the aqueous two-phase systems are applicable in the recovery of proteins from real systems.

\section{Acknowledgements}

The authors are grateful to CNPq for its financial support and DEQ/PPGEQ by encouraging and supporting the research.

\section{References}

[1] Kosikowski, F.V. (1979) Whey Utilization and Whey Products. Journal of Dairy Science, 63, 1149-1160. http://dx.doi.org/10.3168/jds.S0022-0302(79)83389-5

[2] Tashima, L., Correa, S.S., Cruz, A.J.S.D.G. and Jordão, I.M. (2013) Análise comparativa da composição centesimal do soro de leite bovino, caprino e ovino. Anais do Simpósio sobre inovação na indústria de lácteos. Proceedings of Simpósio sobre Inovação na Indústria de 
Lácteos, Campinas, Brazil, 1.

[3] Moor, C.V. and Ha, E.Y.W. (1993) Whey Protein Concentrates and Isolates: Processing and Functional Properties. Critical Reviews in Food Science and Nutrition, 33, 431-476. http://dx.doi.org/10.1080/10408399309527643

[4] Altertsson, P.A. (1971) Partition of Cell Particles and Macromolecules. 2nd Edition, John Wiley \& Sons, New York.

[5] Jayapal, M., Regupathi, L. and Murugesan, T. (2007) Liquid-Liquid Equilibrium of Poly(ethylene glycol) $2000+$ Potassium Citrate + Water at $(25,35 \text {, and } 45)^{\circ} \mathrm{C}$. Journal of Chemical Engineering Data, 52, 56-59. http://dx.doi.org/10.1021/je060209d

[6] Silva, T. M., Minim, L.A., Maffia, M.C., Coimbra, J.S.R., Minim, V.P.R. and Da Silva, L.H.M. (2007) Equilibrium Data for Poly(propylene glycol) + Sucrose + Water and Poly(propylene Glycol) + Fructose + Water Systems from (15 to 45$)^{\circ} \mathrm{C}$. Journal of Chemical Engineering Data, 52, 1649-1652. http://dx.doi.org/10.1021/je700031d

[7] Kyu, T., Zhuang, P. and Mukherjee, P. (1989) Phase Separation Dynamics of Aqueous Hydroxypropyl Cellulose Solution. Polymer Association Structures: Micromulsion and Liquid Crystals, ACS Symposium Series \# 384, M.A. El-Nokaly Ed. 16, 266-283. http://dx.doi.org/10.1021/bk-1989-0384.ch016

[8] Silverio, S.C., Madeira, P.P., Rodriguez, O., Teixeira, J.A. and Macedo, E.A. (2008) $\triangle \mathrm{G}\left(\mathrm{CH}_{2}\right)$ in PEG-Salt and Ucon-Salt Aqueous Two-Phase Systems. Journal of Chemical Engineering Data, 53, 1622-1625. http://dx.doi.org/10.1021/je800154y

[9] Kula, M.R., Kroner, K.H. and Husted, H. (1982) Purification of Enzymes by Liquid-Liquid Extraction, in: Advances in Biochemical Engineering. Fiechter A., Spring Verlag, Berlin, 24, 73-118. http://dx.doi.org/10.1007/3-540-11699-0 11

[10] Albertsson, P.A. (1986) Partition of Cell Particles and Macromolecules. 3rd Edition, John Wiley, New York.

[11] Coimbra, J.S.R., Thomes, J. and Kula, M.R. (1994) Continuous Separation of Whey Proteins with Aqueous Two-Phase Systems in a Graesser Contactor. Journal of Chromatography A, 668, 85-94. http://dx.doi.org/10.1016/0021-9673(94)80095-2

[12] Da Silva, L.H.M. and Meirelles, A.J.A. (2001) Phase Equilibrium and Protein Partitioning in Aqueous Mixtures of Maltodextrin with Polypropylene Glycol. Carbohydrate Polymers, 46, 267-274. http://dx.doi.org/10.1016/S0144-8617(00)00324-6

[13] Mokhtarani, B., Mortaheb, H.R. and Mafi, M. (2011) Partitioning of $\alpha$-Lactoalbumina e $\beta$-Lactoglobulina in Aqueous Two-Phase Systems of Polyvinylpyrrolidone and Potassium Phosphate. Journal of Cromatography B, 879, 721-726.

http://dx.doi.org/10.1016/j.jchromb.2011.02.007

[14] Alves, J.G.L.F., Chumpitaz, LD.A., Silva, L.H.M., Franco, T.T. and Meirelles, A.J.A. (2000) Partitioning of Whey Proteins, Bovine Serum Albumin and Porcine Insulin in Aqueous Two-Phase Systems. Journal of Chromatography B, 743, 235-239. http://dx.doi.org/10.1016/S0378-4347(00)00111-0

[15] Jorge, I.C.F.A. (2011) Phase Equilibrium of the Ternary System Castor Bean BiodieselEthanol-Glycerin Utilizing the Viscosity as a Parameter for Determining the Composition of the Phases. Thesis Ms UFAL, Maceió.

[16] Buffoni, J.N., Bonizzi, I., Pauciullo, A. and Ramunno, L. (2011) Characterization of the Major Whey Proteins from Milk of Mediterranean Water Buffalo (Bubalus bubalis). Food Chemistry, 127, 1515-1520. http://dx.doi.org/10.1016/j.foodchem.2011.02.008

[17] Enne, G., Elez, D., Fondrini, F., Bonizzi, I., Feligini, M. and Aleandri. R., (2005) High- Performance Liquid Chromatography of Governing Liquid to Detect Illegal Bovine Milk's Ad- 
dition in Water Buffalo Mozzarella: Comparison with Results from Raw Milk and Cheese Matrix. Journal of Chromatography, 1094, 169-174.

http://dx.doi.org/10.1016/j.chroma.2005.09.004

[18] Chen, J.P. (1992) Partitioning and Separation of $\alpha$-Lactoalbumina e $\beta$-Lactoglobulina in PEG/Potassium Phosphate Aqueous Two-Phase Systems. Journal of Fermentation and Bioengineering, 73, 140-147. http://dx.doi.org/10.1016/0922-338X(92)90579-J

[19] Graber, T.A., Taboada, M.A., Asenjo, J.A. and Andrews B.A. (2001) Influence of Molecular Weight of the Polymer on the Liquid-Liquid Equilibrium of the Poly(ethylene glycol) + $\mathrm{NaNO}_{3}+\mathrm{H}_{2} \mathrm{O}$ System at 298.15. Journal of Chemical Engineering Data, 46, 765-768. http://dx.doi.org/10.1021/je000372n

[20] Da Silva, L.H.M., Da Silva, M.C.H., Mesquita, A.F., Do Nascimento, K.S., Coimbra, J.S.R. and Minim, L.A. (2005) Equilibrium Phase Behavior of Triblock Copolymer + Salt + Water Two-Phase Systems at Different Temperatures and $\mathrm{pH}$. Journal of Chemical Engineering Data, 50, 1457-1461. http://dx.doi.org/10.1021/je050104v

[21] Chumpitaz, L.D.A. (2002) Whey Protein Separation with Aqueous Biphasic System on a Column of Rotating Disks. PhD Thesis, Unicamp, Brazil.

[22] Coimbra, J.S. (1995) Performance of an Extractor Type Graesser the Separation of Cheese Whey Proteins Using ATS. PhD Thesis, Unicamp, Brazil.

[23] Zuñiga, A.D.G., Coimbra, J.S.R. and Minim, L.A. (2001) Partitional Coefficients of a-Lactoalbumin and b-Lactoglobulin in Aqueous Two Phase Systems: Influence of Molecular Mass. Ciencia y Tecnología Alimentaria, 3, 149-155.

\section{Submit or recommend next manuscript to SCIRP and we will provide best service for you:}

Accepting pre-submission inquiries through Email, Facebook, LinkedIn, Twitter, etc. A wide selection of journals (inclusive of 9 subjects, more than 200 journals)

Providing 24-hour high-quality service

User-friendly online submission system

Fair and swift peer-review system

Efficient typesetting and proofreading procedure

Display of the result of downloads and visits, as well as the number of cited articles Maximum dissemination of your research work

Submit your manuscript at: http://papersubmission.scirp.org/ 